\title{
PKM Kelompok Kerajinan Pengolahan Sampah Plastik Di Kecamatan Kota Tengah Kota Gorontalo
}

\author{
Syamsul, Syaiful Pakaya, Moh. Muhrim \\ Universitas Ichsan Gorontalo \\ Email: tomallawa@gmail.com
}

\begin{abstract}
Abstrak - Kelompok kerajinan pengolahan sampah plastik merupakan kelompok yang terdiri dari ibu-ibu rumah tangga yang mengolah sampah atau limba plastik menjadi suatu produk kerajinan yang memiliki nilai tambah ekonomi bagi anggota kelompok. Selama pembentukannya kelompok tersebut hanya menghasilkan produk kerajinan dari botol plastic bekas seperti pot bunga dan hiasan dinding. Permasalahan yang dialami oleh kelompok tersebut mulai dari proses produksi, manajemen usaha, dan pemasaran. Hasil pelaksanaan melalui program kemitraan masyarakat (PKM) tim pendamping memberikan solusi terkait permasalahan yang dihadapi oleh mitra yakni pemberian materi dan pelatihan mitra sudah mulai menggunakan jenis sampah plastik kantong kresek sebagai produk kerajinan berupa tas tentengan, karangan bunga, dan pas bunga, serta tersedianya mitra penyedia bahan baku yang mendukung produksi. Pemberian materi sekaligus cara membikin laporan keuangan, hasilnya mitra telah memiliki catatan produksi dan penjualan, serta mengetahui omset. Mitra juga diberikan pelatihan keorganisasiaan, hasilnya anggota kelompok sudah melakukan pengerjaan berdasarkan job yang diberikan. Pemberian materi dan pelatihan cara memaasarkan produk, hasilnya mitra telah memiliki media pemasaran online berupa fanpage facebook dan Instagram. Penjaringan mitra pemasaran, dimana mitra telah memiliki mitra pemasaran produk yaitu pada warung-warung dan lapak-lapak di pasar.
\end{abstract}

Kata Kunci: Kerajinan, Pengolahan sampah plastik, Gorontalo, PKM

\begin{abstract}
The plastic waste processing handicraft group is a group consisting of housewives who process waste or plastic waste into a handicraft product that has economic added value for group members. During its formation the group only produced handicraft products from used plastic bottles such as flower pots and wall hangings. The problems experienced by this group start from the production process, business management, and marketing. The results of the implementation through the community partnership program (CPM) the companion team provided solutions related to problems faced by partners, namely providing materials and training partners who have started using plastic plastic waste bags as handicraft products in the form of handbags, flower garlands, and flower fitting, as well as the availability of partners raw material providers that support production. Providing material as well as how to make financial reports, the result is that partners already have production and sales records, and know turnover. Partners are also given organizational training, as a result group members have already done work based on the given job. Providing material and training on how to market products, the result is that partners already have online marketing media in the form of Facebook and Instagram fanpages. Marketing partner networking, where partners already have product marketing partners, namely in stalls and stalls in the market.
\end{abstract}

Keywords: Crafts, Plastic waste processing, Gorontalo, PKM

\section{PENDAHULUAN}

Sampah merupakan permasalahan yang di alami oleh banyak kota-kota besar seiring meningkatnya populasi penduduk kota dan tingginya aktivitas industri serta rumah tangga. Studi mencatat, sekitar 7.000 ton per hari sampah yang di hasilkan di Ibukota Jakarta. Hal yang sama terjadi di Yogyakarta, sekitar 470 ton per hari sampah yang dihasilkan dari aktivitas industri maupun rumah tangga (Sudibyo, Pradana, Budiman \& Budhijanto, 2017)[1]. Persoalan yang serupa juga terjadi di Kota Gorontalo sebagai Ibu Kota provinsi, dimana Kota Gorontalo menghasilkan sampah yang cukup besar dibanding daerah lain disekitarnya. Kota Gorontalo merupakan pemukiman paling padat dibanding daerah lainnya, sekitar $18 \%$ penduduk tinggal di Kota Gorontalo. Berdasarkan data pada Sistem Informasi Pengelolaan Sampa Nasional (SIPSN) periode 2017-2018 tercatat ada sekitar 133,95 ton per hari sampah dihasilkan baik oleh rumah tangga, kantor, pasar, maupun oleh industri di Kota Gorontalo. Dari 133,95 ton sampah per hari terdapat sekitar $21,30 \%$ atau sekitar 28,5 ton per hari sampah jenis plastik.[2]

Produksi jenis sampah plastik di Kota Gorontalo terbesar ke dua setelah sampah sisa makanan. Hal ini jika dibiarkan terus menerus 
jumlah produksinya dapat dipastikan akan terus bertambah yang pada akhirnya mencemari lingkungan. Sampah plastik merupakan salah satu jenis sampah padat yang tidak dapat diurai dalam waktu singkat, membutuhkan waktu 50-100 tahun untuk terurai menjadi tanah. Meskipun sampah plastik membutuhkan waktu yang lama untuk terurai, namun sampah pelastik dapat di daur ulang menjadi beranekaragam kerajinan yang memiliki manfaat ekonomis bagi masyarakat dan sebagai bentuk dukungan penerapan sistem 3R (Reuse, Reduce, dan Recycle) dalam mencegah peningkatan kerusakan lingkungan .

Daur ulang sampah plastik dalam bentuk kerajinan masih jarang ditemukan di Kota Gorontalo, yang banyak dikenal daur ulang sampah plastik dalam bentuk pemilahan kemudian dijual kembali, pada hal sampah plastik jika di olah secara kreatif dapat menjadi peluang bisnis dan memberikan nilai tambah ekonomi bagi masyarakat. Misalnya, membuat tas dari plastik pembungkus kopi, sapu dari plastik botol bekas, tas keranjang dari gelas platik bekas, payung dari plastik pembungkus sunlight bekas, rangkaian bunga, taplak meja, dan banyak lagi produk yang bisa di hasilkan dari sampah plastik.

Kelompok kerajinan pengolahan sampah plastik di Kampung KB Kecamatan Kota Tengah merupakan kelompok yang beranggotakan 8 (lima) orang perempuan Pasangan Usia Subur (PUS). Kelompok ini terdiri dari pasangan usia subur yang tidak produktif secara ekonomi namun berhasrat kuat menjadi wirausahawan. Anggota kelompok kerajinan tergolong keluarga pra sejahatera dan keluarga sejahtera I (KS I). Saat ini, beberapa instansi pemerintah sudah menggunakan produk hasil kerajinan kelompok, seperti yang di gunakan dalam menghias ruangan dan halam kantor Balai Penyulu KB Kecamatan Kota Tengah.

Kelompok tersebut memiliki potensi baik dari segi pengelolaan, sumber daya manusia, dan produksi. Potensi pengelolaan dimana anggota kelompok memiliki komitmen yang tinggi dalam menjalankan kerajinan yang kurang lebih sudah dijalankan 4 tahun bersama anggota. Potensi sumber daya manusia dimana anggota kelompok tergolong usia produktif yang dapat mengelolah kerajinan dengan baik. Potensi produksi dimana bahan baku mudah di peroleh mengingat produksi sampah plastik di Kota Gorontalo yang cukup besar. Selain itu, kelompok juga memiliki peluang usaha yang menjanjikan mengingat gaya konsumsi masa kini suka produk-produk yang memiliki keunikan, terlebih jika hasil kerajinan memiliki keunikan tersendiri tentu akan menghasilkan produk yang memiliki nilai jual tinggi. Berikut diuraikan situasi mitra dari hasil penelitian yang telah dilakukan pengusul dalam penelitian kompeteitif dosen pemula tahun 2019, dari bidang produksi, manajemen usaha dan permasalahan sumberdaya yang dihadapi.

Bidang produksi, belum optimalnya pembuatan produk dari pengolahan sampah plastik dimana kelompok kerajinan masih berfokus pada pengolahan botol plastik saja yang dihasilkan rumah tangga, pada hal sampah bungkusan plastik dan gelas plastik juga dapat diolah yang tidak kalah dengan hasil dari botol plastik. Lambatnya menghasilkan produk kerajinan dikarenakan bahan baku (sampah plastik) yang digunakan hanya diperoleh dari pengumpulan sendiri yang diambil sampah plastik di sekolah dan dari rumah tetangga. Belum mengedepankan kualitas dari roduk yang dihasilkan hal ini terlihat irisan-irisan produk kerajinan masih kasar. Produk kerajinan yang dihasilkan masih kasar dikarenkan penggunaan alat dalam pembuatan terbatas hanya menggunakan alat seadanya saja. Sebagaimana yang dikemukakan Aminudin dan Nurwati, (2019) dalam jurnalnya bahwa peralatan dan bahan yang dapat digunakan dalam pembuatan karya seni limbah adalah bungkus plastik bekas bungku white copy, bungkus permen, bekas bukungkus rinso dan bungkus molto.[3] Hal yang sama dikemukakan oleh Diana,et al., (2017) dalam hasil penelitiannya bahwa pemanfaatan sampah plastik dari limbah kemasan detergen, sabun, pewangi pakaian dan plastik kresek menjadi tas dan dompet menjadi produk kerajinan bernilai ekonomis [4]. Begitupun yang dikemukakan dari hasil pengabdian Syamsul, Rahmatia, \& Pakaya, (2019) bahwa permasalahan kerajinan terkait dengan penyedia bahan baku dan keterbatasan peralatanyang digunakan [5]

Bidang manajemen usaha, bahwa produk yang dihasilkan masih terbatas dikarenakan tidak adanya pelatihan yang pernah diberikan kepada anggota kelompok, produk yang dihasilkan berdasarkan kreativitas anggota kelompok semata. Pengelolaan keuangan yang sangat terbatas mempengaruhi rendahnya kualitas produk hasil kerajinan dikarenakan modal usaha berasal dari patungan anggota kelompok sehingga kelompok tidak berani memproduksi jika tidak ada pesanan, selain itu tidak adanya catatan keuangan dari anggota kelompok yang bisa saja suatu waktu akan menghentikan proses kerajinan karena besarnya keuntungan dan modal tidak bisa dibedakan. Minimnya sistem kerja dari anggota kelompok dimana anggota kelompok menjalankan seluruh proses kerajinan sehingga membutuhkan waktu yang lama untuk menciptakan produk. Situasi mitra pada bidang manajemen usaha terkait pelatihan juga diungkap 
dari hasil pengabdian Fatoni, et al., (2017) yang telah di publikasikan mengemukakan bahwa peserta yang mengikuti pelatihan menunjukkan adanya perubahan ke arah yang lebih baik tentang perlakuannya terhadap sampah. Peserta memiliki wawasan akan pentingnya memilah sampah dan kesadaran ekonomi bahwa barang yang dibuang ternyata bisa menjadi produk yang bisa dijual dengan harga pantas[6]. Begitupun yang dikemukakan dari hasil pengabdian Syamsul, Rahmatia, \& Pakaya, (2019) bahwa manajemen usaha dalam produk kerajinan tidak adanya pencatatan keuangan sehingga tidak bisa mengetahui besarnya keuntungan dan biaya yang digunakan, selain itu cendrung tidak memiliki pembagian kerja dalam memproduksi kerjinan [5]

Bidang pemasaran, meskipun usaha kelompok kerajinan sudah lama dijalankan namun kendala yang sering dihadapi kelompok adalah memasarkan produk kerajinan. Permintaan produk dari kelompok kami masih seputar tetangga dan instansi pemerintah kelurahan dan kecamatan. Belum adanya kepastian harga per produk, karena di buat berdasarkan pesanan saja. Model pemasaran yang bersifat tradisional dari mulut ke mulut (word of mouth). Belum pernah diperkenalkan secara online, misalnya di pasarkan pada facebook portal jual beli Gorontalo, dan media lainnya. Selain itu, pemerintah Kota Gorontalo belum mengenal kelompok kerajinan sampah plastik dengan tidak terdaftarnya dalam kelompok UMKM sehingga jika ada pameranpameran produk kerajinan kelompok tidak pernah diikutkan. Situasi mitra bidang pemasaran juga telah diungkap dari hasil penelitian Hardianti, et al., (2017) mengemukakan bahwa pemasaran produk kerajinan sangatlah terbatas jika hanya menggunakan pembukaan stand produk kerajinan di acara bazar/pameran dan promosi hanya dilakukan pada saat kegiatan posyandu. Selain itu, produk hendaknya menggunakan label baik dalam bentu slogan maupun gambar.[7] Hal yang sama di kemukakan dari hasi pengabdian Febrianti dan Fauzan, (2017) bahwa untuk memperkenalkan produk kerajinan dapat dilakukan dengan cara menitipkan di took souvenir yang berada di daerah wisata, selain menjadikan wisata banyak dikunjungi juga produk dapat dikenal orang lain sehingga adanya pemesanan pada produk tersbut [8]. Begitupun yang dikemukakan dari hasil pengabdian Syamsul, Rahmatia, \& Pakaya, (2019) bahwa kelompok pengrajinan memiliki kendala pemasaran dalam memeasarkan produk kerajinannya dikarenakan keterbatasan pengetahuan dan penguasaan teknologi [5].

\section{METODE PELAKSANAAN}

Metode pelaksanaan yang telah dilakukan Tim PKM kepada mitra kelompok kerajinan sampah plastik berupa pemberian materi jenis sampah plastik yang dapat digunakan dalam menciptakan produk kerajinan. Melakukan penjaringan mitra yang menyediakan bahan baku plastik di tempat-tempat pembuangan sampah di kota Gorontalo. Melakukan pelatihan pengolahan sampah plastik menjadi produk kerajinan sekaligus pemberian alat bantu produksi berupa mesin jahit dan setrika. Memberikan materi dan pelatihan pembuatan laporan keuangan sederhana. Melakukan pelatihan keorganisasi kepada kelompok mitra. Melakukan pelatihan cara memasarkan online dengan media sosial. Melakukan pendampingan dalam menjamin mitra usaha. Melakukan monitoring dan evaluasi untuk menjaga keberlanjutan usaha kerajinan.

\section{HASIL DAN PEMBAHASAN}

Hasil pelaksanaan pendampingan pada mitra kelompok kerajinan pengolahan sampah plastik dapat diuraikan sebagai berikut:

Pemberian materi penggunaan sampah plastik lainyya, dimana dalam pelaksanaan kegiatan pendampingan Tim PKM memaparkan jenis sampah plastik yang dapat diolah menjadi produk kerajinan. Hasil kegiatan menunjukkan bahwa setelah mitra kelompok diberikan pengetahuan dalam penggunaan jenis plastik yang bisa diolah menjadi produk kerajinan, maka mitra kelompok memilih sampah plastik kantong kresek dan gelas plastik untuk diolah menjadi kerajinan, hal ini dikarenakan ketersediaan jenis sampah tersebut sangat banyak dan mudah didapatkanyang menjadi jenis sampah yang lebih mudah di dapatkan dan memiliki keunikan terseindiri apabila dijadikan produk kerajinan.

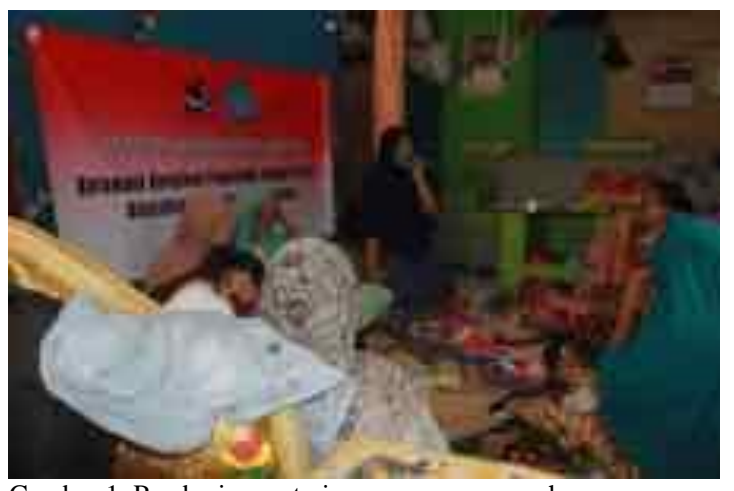

Gambar 1. Pemberian materi penggunaan sampah 
Setelah memberikan pemahaman dan pengetahuan kepada kelompok tentang jenis sampah yang dapat digunakan dalam olahan menjadi produk kerajinan, juga dilakukan penjaringan mitra untuk menjamin ketersediaan bahan baku. Bahan baku kerajinan adalah sampah plastik, oleh karenanya dilakukan penjaringan mitra penyedia bahan baku di tempat-tempat pembuangan sampah guna ketersediaan plastik sebagai bahan baku. Selain itu, juga dilakukan koordinasi dengan pemerintah setempat dan Dinas Perindustrian dan Perdagangan Kota Gorontalo. Kegiatan ini menjadi penting dikarenakan dalam rantai produksi ketersediaan mitra sangat mendukung kelancaran produksi, dengan menjalin mitra tersebut kelompok lebih mudah nantinya memperoleh bagan baku untuk kerajinan.

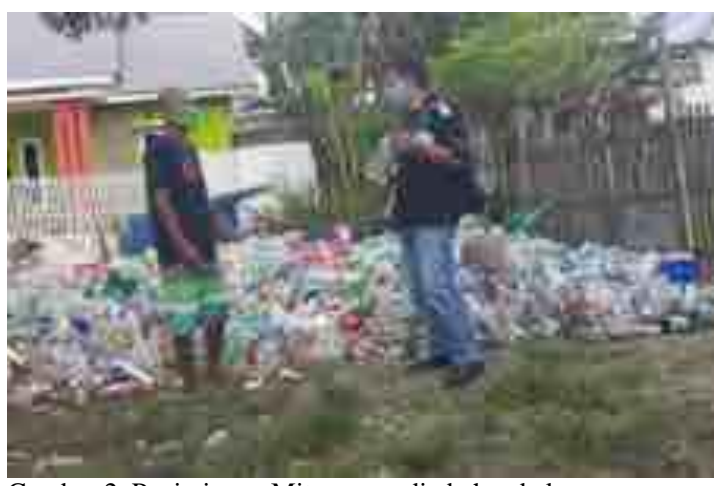

Gambar 2. Penjaringan Mitra penyedia bahan baku

Kemudian, kegiatan berikutnya adalah pemberian pelatihan dan bimbingan cara-cara mengolah sampah setelah mendapatkan sebelumnya materi tentang penggunaan jenis sampah. Pada poses pelaksanaan pelatihan yang dilakukan sebanyak 8 kali pertemuan hingga produk kerajinan tercipta. Para anggota kelompok sangat serius dan antusias mengikuti seluruh rangkaian kegiatan. Dari keseriusan para anggota, sehingga hasil yang dicapai dalam Pelatihan dan bimbingan tersebut dimana melahirkan produk dalam bentuk tas plastik yang 99 persen bahannya dari kantong plastik kresek. Kemudian, karangan bunga yang dipadukan antara kantong plastik kresek, botol plastik dengan glas plastik minuman, dan pas bunga yang 75 persen bahannya dari kantong kresek. Selain itu, Tim PKM memberikan bantuan alat pendukung produksi berupa mesin jahit dan Setrika. Hal ini dapat dilihat pada gambar berikut ini.

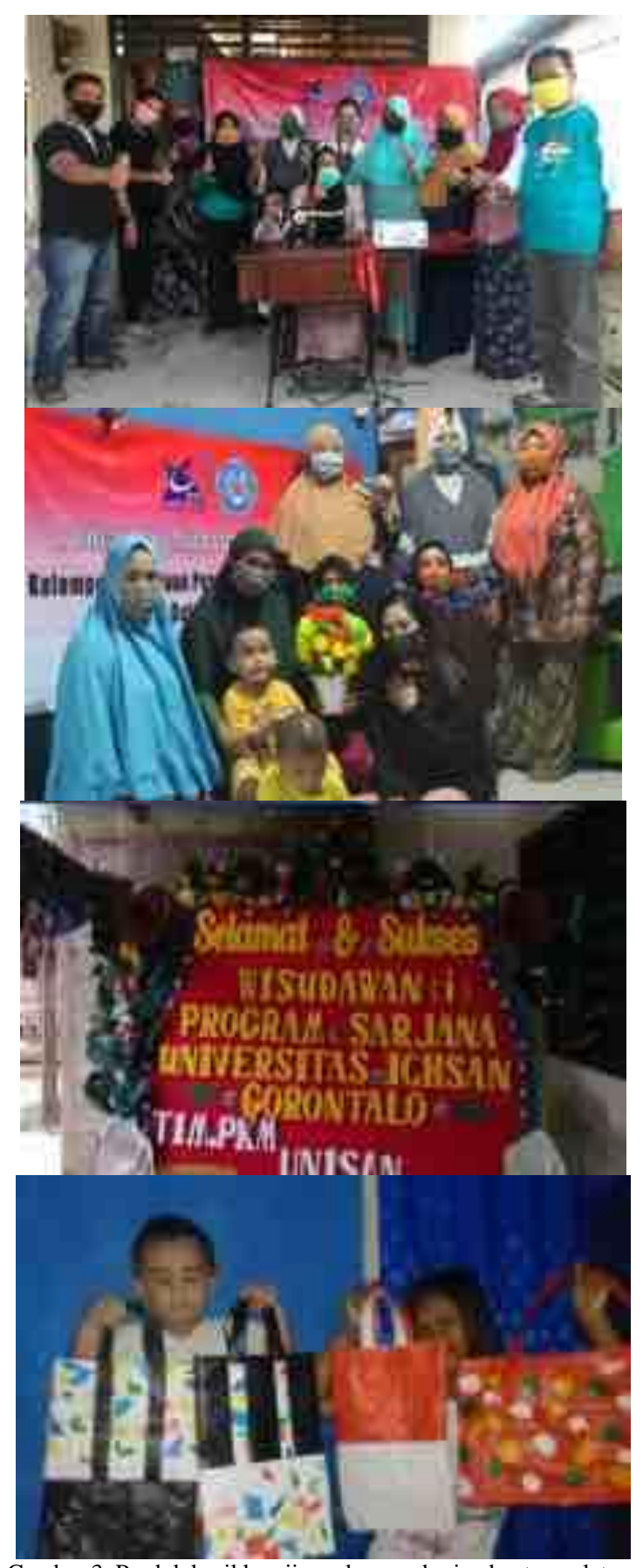

Gambar 3. Produk hasil kerajinan dan pemberian bantuan alat

Pemberian pelatihan pembuatan keorganisasian dan laporan keuangan. Hasil yang dicapai anggota kelompok telah mengerjakan aktivitas produksi berdasarkan pada pekerjaan yang telah ditentukan sehingga pembuatan produk kerajinan lebih efisien dan efektif. Selain itu, mitra memiliki buku jurnal keuangan yang digunakan dalam mencatat seluruh transasksi dari aktivitas usaha kelompoknya. 


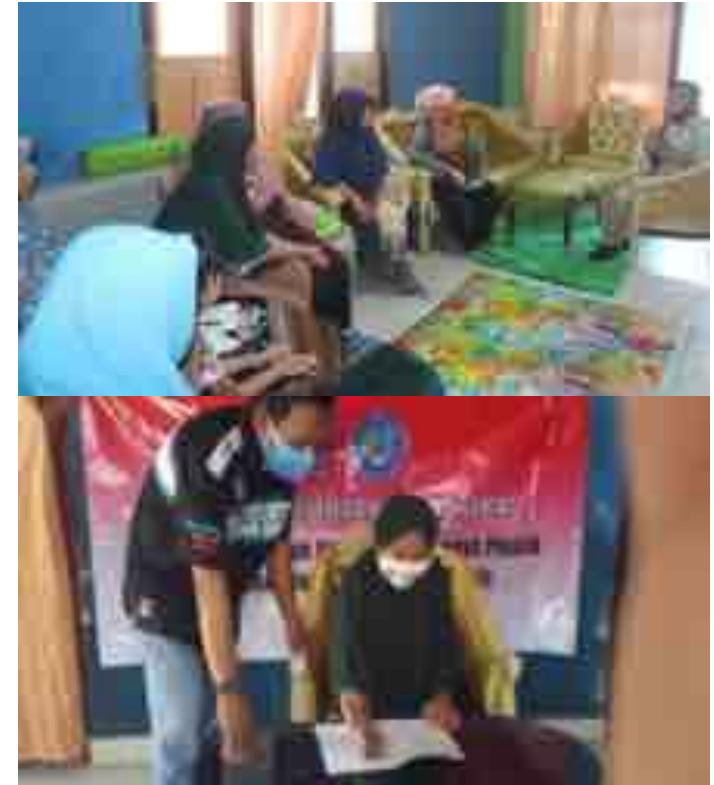

Gambar 4. Pelatihan keorgnisasian dan pembuatan laporan keuangan

Aktivitas akhir produksi adalah memasarkan, oleh karenanya Tim PKM memberikan materi dan pelatihan cara memasarkan produk melalui media sosial. Hasilnya mitra telah memahami cara-cara memasarkan melalui media sosial, dan telah memiliki akun fanpage facebook khusus usaha kerajinannya

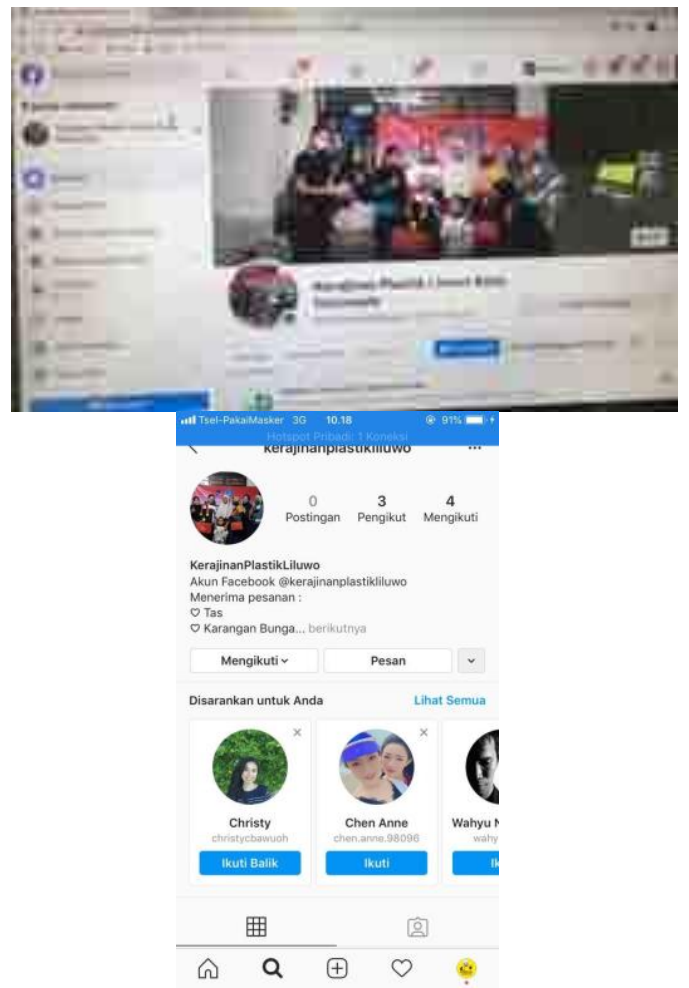

Gambar 5. Media pemasaran online produk kerajinan
Berdasarkan pelaksanaan solusi yang ditawarkan dari permasalahan mitra, maka dapat

disimpulkan bahwa pelaksanaan Program Kemitraan Masyarakat (PKM) yang dilakukan oleh Tim bersama dengan Kelompok Kerajinan Pengolahan Sampah Platisk memberikan hasil peningkatan produksi. Adapun kemajuan yang diperoleh mitra setelah kegiatan pendampingan dapat dilihat pada Tabel 1.

\begin{tabular}{|c|c|c|}
\hline Permasalahan & $\begin{array}{l}\text { Sebelum } \\
\text { Kegiatan }\end{array}$ & $\begin{array}{l}\text { Setelah } \\
\text { Kegiatan }\end{array}$ \\
\hline \multirow{3}{*}{$\begin{array}{l}\text { Aspek } \\
\text { Produksi }\end{array}$} & $\begin{array}{l}\text { Penggunaan } \\
\text { bahan terbatas } \\
\text { hanya dari } \\
\text { botol plastik } \\
\text { bekas dan } \\
\text { produknya } \\
\text { terlihat kasar }\end{array}$ & $\begin{array}{l}\text { Telah menggunakan } \\
\text { platik kresek, botol } \\
\text { plastik dan gelas } \\
\text { plastik sebagai produk } \\
\text { kerajinan yang terdiri } \\
\text { dari tas tentengan, } \\
\text { karangan bunga, dan } \\
\text { pas bunga }\end{array}$ \\
\hline & $\begin{array}{l}\text { Tidak } \\
\text { menggunakan } \\
\text { alat } \\
\text { pendukung } \\
\text { pembuatan } \\
\text { kerajinan }\end{array}$ & $\begin{array}{l}\text { Telah menggunakan } \\
\text { alat pendukung } \\
\text { pembuatan kerajinan } \\
\text { berupa mesin jahit dan } \\
\text { setrika }\end{array}$ \\
\hline & $\begin{array}{l}\text { Produk hanya } \\
1 \text { jenis saja }\end{array}$ & $\begin{array}{l}\text { Produk sudah terdri } \\
\text { dari } 3 \text { jenis, yaitu tas } \\
\text { tentengan, karangan } \\
\text { bunga, dan pas bunga }\end{array}$ \\
\hline \multirow{2}{*}{$\begin{array}{l}\text { Manajemen } \\
\text { Usaha }\end{array}$} & $\begin{array}{l}\text { Belum ada } \\
\text { laporan } \\
\text { keuangan } \\
\text { Mitra }\end{array}$ & $\begin{array}{l}\text { Tersedia laporan } \\
\text { keuangan }\end{array}$ \\
\hline & $\begin{array}{l}\text { Belum ada } \\
\text { pembagian } \\
\text { kerja dalam } \\
\text { kelompok }\end{array}$ & $\begin{array}{l}\text { Sudah ada pembagian } \\
\text { kerja dalam kelompok }\end{array}$ \\
\hline $\begin{array}{c}\text { Aspek } \\
\text { Pemasaran }\end{array}$ & $\begin{array}{l}\text { Belum ada } \\
\text { bantuan media } \\
\text { pemasaran } \\
\text { secara online }\end{array}$ & $\begin{array}{l}\text { Sudah ada media } \\
\text { online dalam bentuk } \\
\text { fanpages Facebook }\end{array}$ \\
\hline
\end{tabular}

\section{KESIMPULAN}

Program Kemitraan Masyarakat (PKM) pada Kelompok Kerajinan pengolahan Sampah Plastik Di Kelurahan Dulalowo Kota Gorontalo merupakan program pengabdian masyarakat yang bertujuan mengoptimalkan dan meningkatkan kesejahteraan mitra serta ikut dalam mengurangi timbunan sampah plastik dengan memberikan pengetahuan dan ketrampilan dalam mengelolah usaha kelompoknya, keterampilan mengolah kerajinan sampah plastik, menigkat pemahaman dan pengetahuan dalam mengelola keuangan usahanya, dan meningkatkan penjualan melalui 
pemasaran yang lebih luas. Serta menunjang kegiatan produksi Kelompok Kerajinan pengolahan Sampah Plastik Di Kelurahan Dulalowo Kota Gorontalo maka tim pengusul PKM memberikan bantuan berupa peralatan mesin jahit dan setrika untuk diguanakan saat produksi

\section{UCAPAN TERIMAKASIH}

Ucapan terima kasih kami ucapakan kepada Direktorat Riset Dan Pengabdian Masyarakat (DRPM) Kemenristek-Brin atas pembiayaan yang diberikan pada pelaksanaan program kemitraan masyarakat (PKM) Kelompok Kerajinan Pengolahan Sampah Palastik Kecamatan Kota Tengah Kota Gorontalo. Kepada Lembaga Pengabdian Masyarakat Universitas Ichsan Gorontalo terima kasih atas kerja sama yang baik selama ini.

\section{DAFTAR PUSTAKA}

[1]. Sudibyo, H., Pradana, Y. S., Budiman, A., \& Budhijanto, W. (2017). Municipal Solid Waste Management in Indonesia-A Study about Selection of Proper Solid Waste Reduction Method in DI Yogyakarta Province. Energy Procedia, 143, 494-499.

[2]. Kementerian Lingkungan Hidup dan Kehutanan Republik ndonesia. (2018). Informasi Pengelolaan Sampa Nasional (SIPSN): Data Pengolahan Sampah Kota Gorontalo periode 2017-2018. http://sipsn.menlhk.go.id Akses September 2020

[3]. Aminuddin, Nurwati. (2019). Pemanfaatan Sampah Plastik Menjadi Kerajinan Tangan
Guna Meningkatkan Kreatifitas Warga Sekitar Institut Teknologi dan Bisnis Ahmad Dahlan (ITB-AD) Jakarta. Jurnal Abdimas BSI, 2(1), 66-79.

[4]. Diana, S., Marlina, Amalia, Z., \& Elwina. (2017). Pemanfaatan Sampah Plastik Menjadi Produk Kerajinan Tangan Bernilai Ekonomis Bagi Remaja Putus Sekolah. Jurnal Vokasi: Jurnal hasil-hasil Penerapan IPTEKS dan Pengabdian Kepada Masyarakat. 1(1), 6873.

[5]. Syamsul, Rahmatia, \& Pakaya, S. (2). PKM Kelompok Kerajinan Upia Karanji Bayalo Desa Motinelo Kecamatan Tabongo Kabupaten Gorontalo. Jati Emas (Jurnal Aplikasi Teknik dan Pengabdian Masyarakat), $3,228-232$

[6]. Fatoni, N., Imanuddin L, R., \& Darmawan, A. R. (2017). Pendayagunaan Sampah Menjadi Produk Kerajinan. Dimas: Jurnal Pemikiran Agama untuk Pemberdayaan. 17(1), 83-96.

[7]. Hardianti, D., Abas, T., \& Ningsih, M. P. (2017). Persepsi Kader PKK Tentang Daur Ulang Limbah Plastik Berbasis Home Industry di Desa Cilame Kabupaten Bandung Barat. Jurnal Family Edu. 3(1), 73-79.

[8]. Febrianta, Y., \& Fauzan, A. (2017). Pelatihan Pembuatan Kerajinan Berbahan Plastik Bekas. Jurnal Pengabdian Dan Pemberdayaanmasyarakat LPIP UMP. 1(1), 25-28. 